\title{
GHEVOND ALISHAN'S LITERARY ACTIVITY THROUGH THE LIGHT OF RUSSIAN INTERPRETATIONS
}

\author{
ZARUHI HAYRYAN \\ National Academy of Sciences of the Republic of Armenia, \\ International Scientific-Educational Center, \\ PhD, Associate Professor \\ L UIZA GASPARYAN \\ National Academy of Sciences of the Republic of Armenia, \\ Institute of Literature after M. Abeghian, \\ $\mathrm{PhD}$, Senior Researcher
}

https://doi.org/10.52853/25792903-2021.2-zhlg

\section{Abstract}

The history of Russian-Armenian literary relationships is one of the brightest and most significant events of the time. It undoubtedly enhanced the mutual cultural heritage and left a profound mark on the worldview, moral and aesthetic values of Armenian and Russian writers, translators, and literary critics.

Since the beginning of the 20th-century Armenian culture, mainly Armenian literature, arouse great interest among such outstanding classics, as M. Gorky, V. Bryusov, A. Blok, O. Mandelstam A. Bely, A. Akhmatova and others. They only appreciated its aesthetic and stylistic texture but al so embarked on the laborious work of translating its best achievements into Russian.

In this sense, the anthology "The Poetry of Armenia from Ancient Times to the Present" in 1916 can be considered a significant cultural event It was edited by Valery Bryusov, who also wrote the introductory part of the work.

The publication was carried out with M. Gorky's direct assistance and support. It should be noted that many Russian translations done by V. Bryusov and A. Blok are still brilliant samples of the artistic heritage of translation.

The present work focuses on the evaluations and interpretations of Russian critics (V. Bryusov, Y. Veselovsky) of the creative heritage of Gh. Alishan, his poetic individuality and the influence on the development of the literary process of that time. It also reveals the role of Russian poets, translators and literary critics in promoting the publication and popularization of Bryusov's anthology as a significant cultural event of the time.

The section of the anthology "Poetry of Western Armenians" includes the most famous poems of Gh. Alishan, M. Peshiktashlyan, P. Duryan, Si pil, L. Shant, and others are parallelly illustrated by the excellent translations of V. Bryusov, S. Shervinsky, V. Khodasevich, K. Balmont, S. Bobrov and others. 
The scientific research has shown that among Russian poets and translators, Bryusov was one of the first interested in Gh. Alishan's literary works and his bright poetic individuality.

It can be explained by the fact that Alishan was a well-known representative of Wester Armenian poetry and a comprehensive creator of his time, a man with encyclopedic knowledge. In addition, he was a historian, philosopher, translator, phil osopher, geographer who devoted his whole life to science and enlightenment.

Bryusov was al so a gifted man. He had a poetic talent; he contributed to improving the Russian dial ect, elevating it to a new, higher level.

Consequently, there are many common features between Bryusov and Alishan. These are the breadth of the intellectual range, brilliant knowledge of languages and world literature, devotion to scientific activities, profound love for their Motherland, its cultural values and the highest level of humanism Undoubtedly, they were outstanding figures of their era who made a significant contribution to the development of culture, science and literature.

This article is an attempt at a comprehensive study of the principles of the Russian translation theory used in the translation of Armenian literature, with particular reference to the poem "Hrazdan", an extract from Gh. Alishan's patriotic lyrics.

The proficiency of Russian translators and the revelation of Armenian linguistic and national characteristics hel ped them interpret the linguo-stylistic peculiarities of the original and recreate their equival ent counterparts.

Keywords and phrases: Valery Bryusov, Russian translation, Jury Veselovsky, Armenian literature, Ghevond Alishan, Armenian Patriotism, poetry, cultural heritage. 


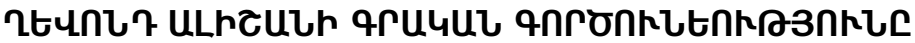

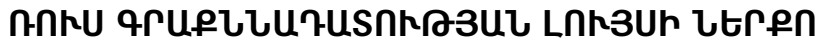

\author{
RUrnh<n <Uзr3u乙

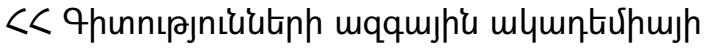

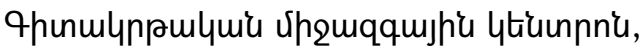

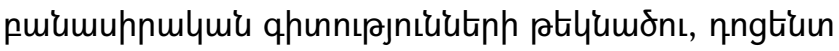

\section{LกRคRU 9UUTUก3U乙}

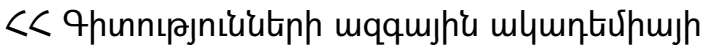

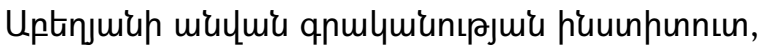

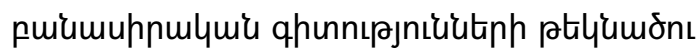

\section{<urumnnunuqpp}

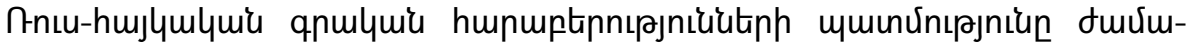

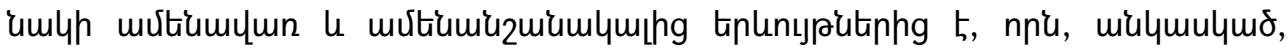

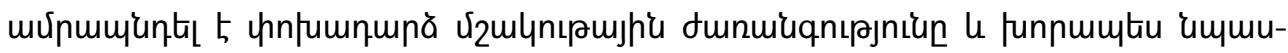

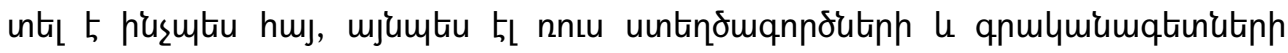
m2łumphnalqurưuin:

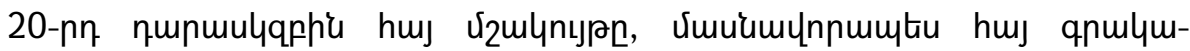

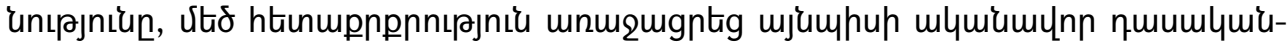

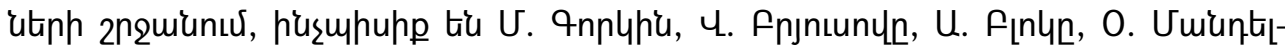

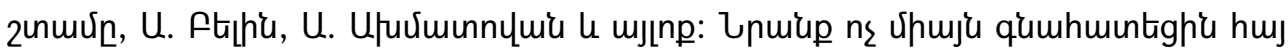

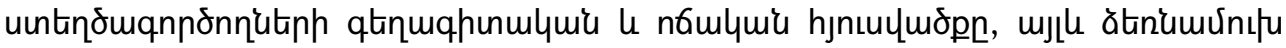

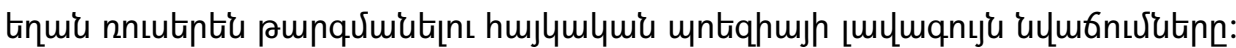

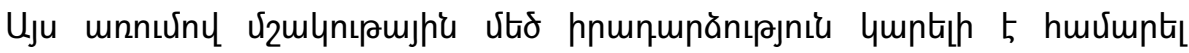
«Поэзия Армении с древнейших времен до наших дней» mupnцnqhuј hpu-

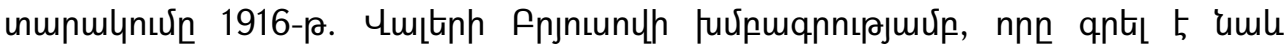

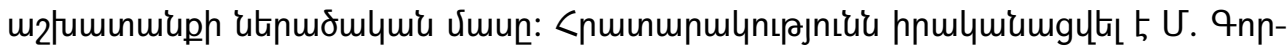

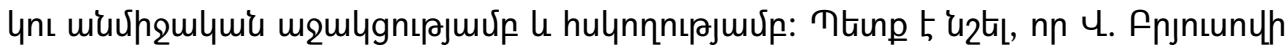

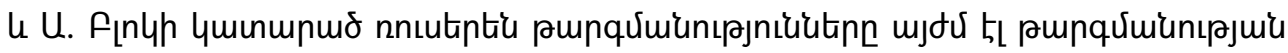

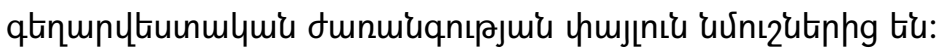

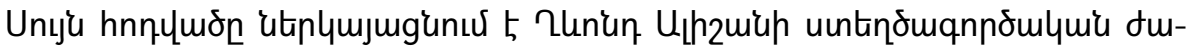

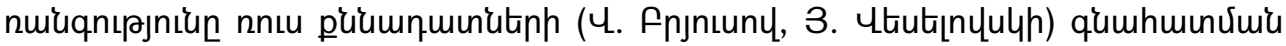

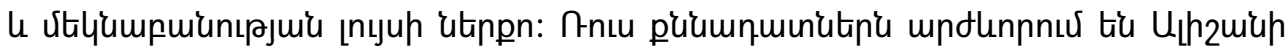

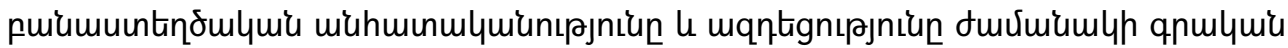

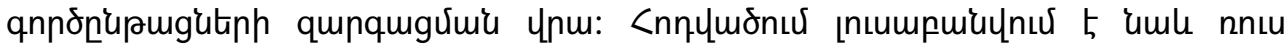




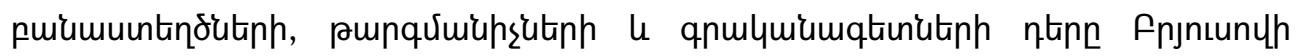

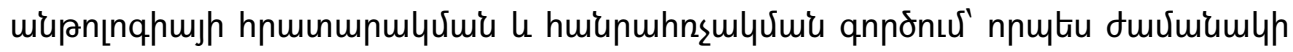
qLlumųn র্র

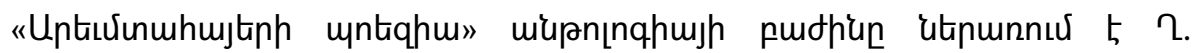

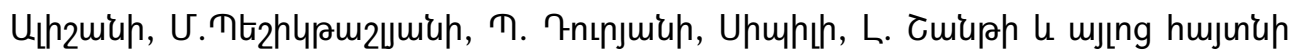

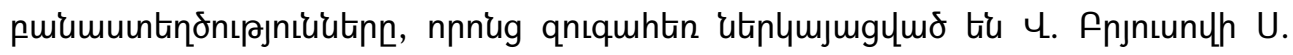

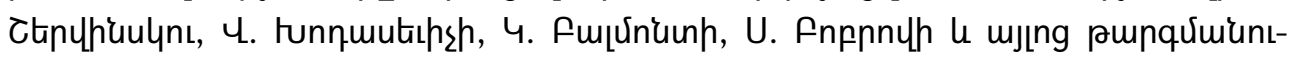
pjnıưutitn:

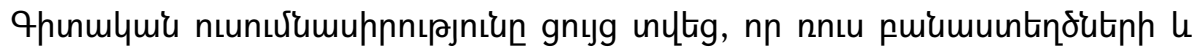

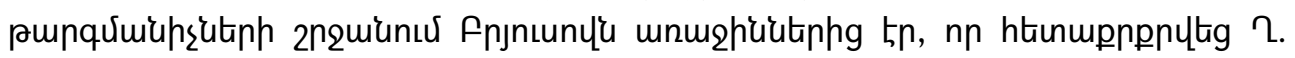

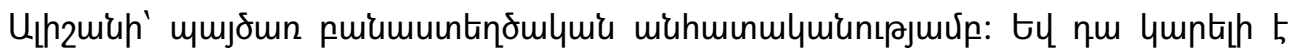

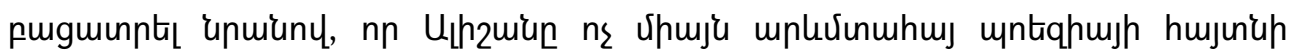

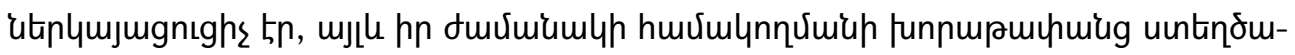

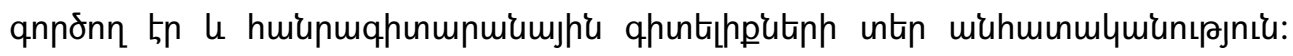

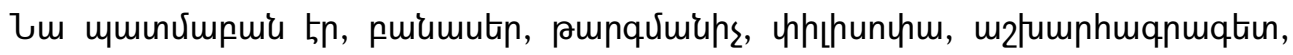

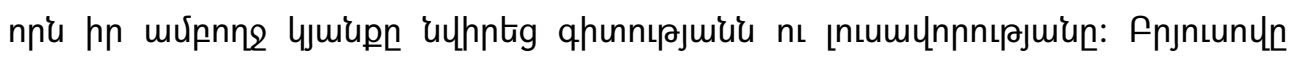

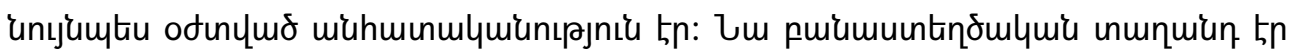

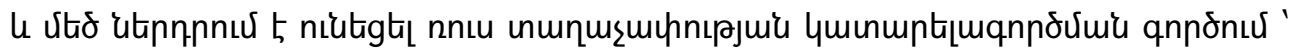

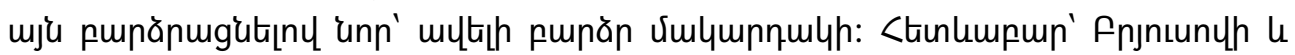

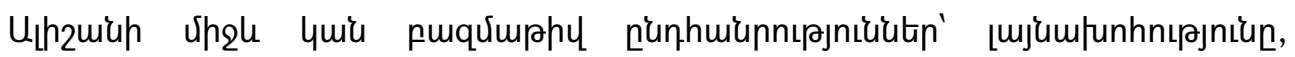

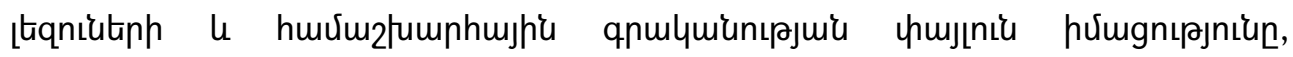

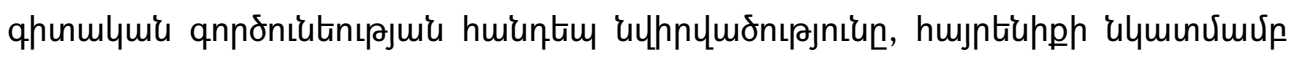

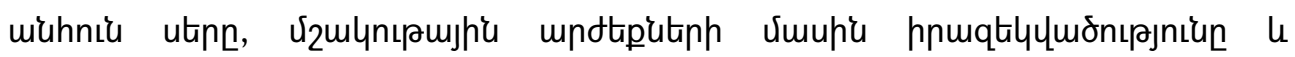

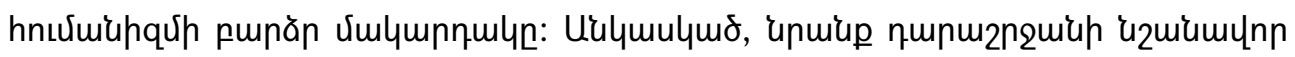

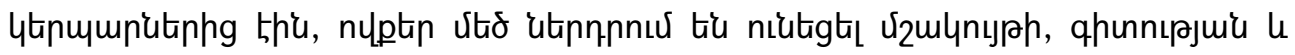
qnulymiunıрjuiu qunqugưuiu qnnonus:

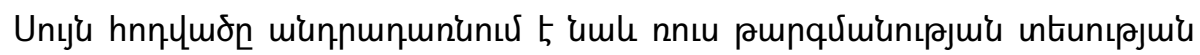

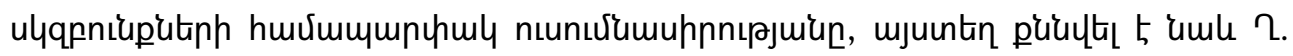

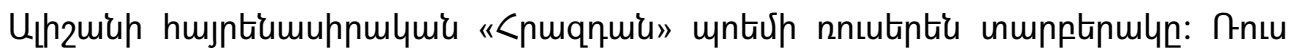

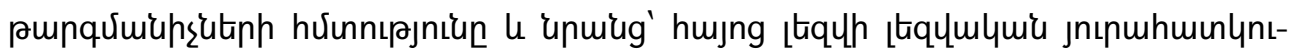

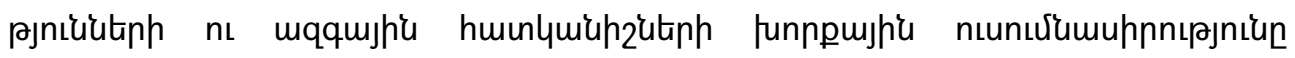

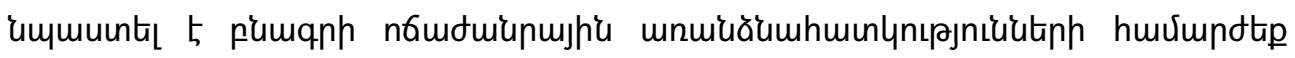
ytapuuuntindơuiun:

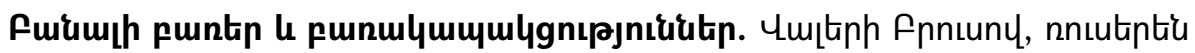

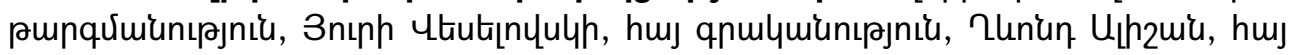

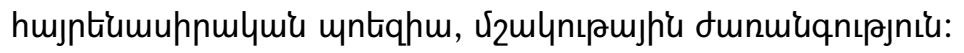




\title{
ЛИТЕРАТУРНАЯ ДЕЯТЕЛЬНОСТЬ ГЕВОНДА АЛИШАНА ПОД ПРИЗМОЙ РУССКОЙ ИНТЕРПРЕТАЦИИ
}

\author{
ЗАРУИ АЙРЯН \\ Национальная академия наук Республики Армения \\ Международный научно-образовательный центр \\ кандидат филологических наук, доцент \\ ЛУИЗА ГАСПАРЯН \\ Национальная академия наук Республики Армения \\ Институт литературы им. М. Абегяна \\ кандидат филологических наук
}

\section{Аннотация}

История русско-армянских литературных взаимосвязей является одной из ярчайших и значимых страниц в жизни двух народов чтоб несомненноб сыграло роль, в деле сближения и обогащения их культурного наследия, отложив глубокий след на мировоззрении, нравственных и эстетических ценностях как армянских, так и русских писателей, поэтов-переводчиков, литературных критиков.

В статье отмечается, что с начала XX века армянская культура, в частности, литература, вызывала большой интерес у таких выдающихся мастеров слова, как М. Горький, В. Брюсов, А. Блок, О. Мандельштам, А. Белый, А. Ахматова и другие, которые не только оценили и полюбили ее, но и с большим вдохновением стали переводить лучшие ее достижения на русский язык.

Большим культурным событием для двух народов было издание антологии «Поэзия Армении с древнейших времен до наших дней», вышедшей в свет в 1916 году под редакцией и со вступительной статьей Валерия Брюсова. Издание осуществилось при непосредственном содействии и поддержке Горького. Отметим, что многие переводы В. Брюсова и А. Блока из антологии до сих пор являются образцами высокого переводческого искусства.

В статье исследованы оценки русских критиков, в частности, В. Брюсова, Ю. Веселовского, творческого наследия Алишана, его поэтическая индивидуальность, выделены также их научные исследования по развитию литературного процесса того времени. В ней выявлена и роль русских поэтов-переводчиков, литературных критиков в содействии издания и популяризации антологии Брюсова как большого культурного события в жизни двух народов.

В раздел антологии "Поэзия турецких армян" вошли наиболее известные стихотворения из поэзии Г. Алишана, М. Пешикташляна, П. Дуряна, Сипил, Л. Шанта и других, которые представлены прекрасными переводами В. Брюсова, С. Шервинского, В. Ходасевича, К. Бальмонта, С. Боброва и других. 
Исследование данной темы свидетельствует, что среди русских поэтовпереводчиков Брюсов одним из первых проявил большой интерес к творчеству Алишана, к его яркой поэтической индивидуальности. И этот факт можно объяснить тем, что Алишан был не только известным представителем поэзии турецких армян, но и всесторонне образованным человеком своего времени, человеком энциклопедических знаний - полиглот, историк, филолог, переводчик, философ, географ, посвятивший всю свою жизнь служению науке, просвещению. Те же качества всесторонне одаренной личности можно выделить и у самого Брюсова, который также был одарен высшим поэтическим талантом, также внес большой вклад в совершенствование русского стихосложения, подняв его до нового, более высокого уровня.

Следовательно, между Брюсовым и Алишаном можно выделить много общих черт. Это, в первую очередь, широта интеллектуального диапазона, блестящее знание языков, всемирной литературы, поэтическая, переводческая, а также научная деятельность, глубокая любовь к своей стране, ее культурным ценностям, высший гуманизм и т. д., что и позволяет заключить, что они были выдающимися деятелями своей эпохи, внесшими большой вклад в развитие культуры, науки, литературы.

В основе данной статьи лежит всестороннее исследование принципов теории русского перевода, использованных при переводе стихов армянских авторов, в частности, при переводе стихотворения «Раздан» из патриотической лирики Гевонда Алишана.

Мастерство русских переводчиков, а также раскрытие армянских языковых и национальных особенностей, помогли им воссоздать, интерпретировать текстовый контекст оригинала и воссоздать их эквиваленты.

Ключевые слова и словосочетания: Валерий Брюсов, русский перевод, Юрий Веселовский, армянская литература, Гевонд Алишан, армянская патриотическая поэзия, культурное наследие.

\section{Introduction}

The Russian-Ammenian literary relationships have significant and profound historical roots, which even nowadays play an indispensable role in the enrichment of mutual cultural-traditional heritage, aesthetics and literary values of writers, translators and literary critics. Since the beginning of the twentieth-century Armenian literature made a remarkable impact on such outstanding masters of verbal creativity, as $M$. Gorky, V. Brusov, A. Blok, O. Mandelstam, A. Akhmatova and others who not only appreciated and eval uated the A rmenian writers but al so with great inspiration initiated the translation of their best pieces of verbal creativity into Russian.

Underlying the importance of literary translation, the Armenian theorist $\mathrm{L}$. Mkrtchyan stated that the translation of literature aims at enhancing the linguo-cultural 
communication of nations and their mutual relations in all spheres of human life [5, p.9].

One cannot fail to observe that for equivalent translation, practitioners should carry out multifaceted strategies involving linguistic and extralinguistic awareness, thorough contextual interpretation and the possibility to interconnect two cultures: the source culture and the target culture [7, p. 68].

The present research carries out theoretical and methodological works of Russian translation theorists and literary critics with particular reference to V. Bryusov and Y. Veselovsky. They highlighted the exclusive richness of A rmenian literature, the peculiar features of Armenian literary genres, style and language. Furthermore, they underlined the fundamental principles and mechanisms of the art of literary translation of Armenian poetry and emphasized the pivotal importance of developing RussianArmenian literary relationships. The research material is the collection of translated Armenian poetry done by Russian translators with particular reference to Ghevond Alishan's patriotic poetry.

The methodological approach of the study is multifaceted, as it comprises; 1. Theoretical illustration of the art of translation; 2 . Interpretation of the genre and epoch of the time; 3. Linguo-stylistic and linguo-poetic analysis of poem; 3. The comparative analysis of the original and the translation.

\section{RUSSIAN ART OF TRANSLATION AND GHEVOND ALISHAN}

A great cultural-literary event for the development of Russian-Armenian relations was the publication of the anthology entitled "The Poetry of Armenia from Ancient Times to the Present" in 1916. The introductory part of the anthology is abundant with $V$. Bryusov's valuable scientific data and interpretations. The publication was carried out with M. Gorky's direct assistance and support.

When V. Bryusov got acquai inted with the Armenian literature, he immediately emphasized the necessity of its translation, thus pointing out that each educated person should perceive its wisdom and philosophy, its beauty and charm The theorist stated that Armenian poetry unveils a new world abundant with stylistically colourful overtones and melodies for the Russian reader. Therefore, it should be truthfully eval uated as much as other verbal creativities of world literature, like Dante's "Human comedy", Shakespeare's drama and Victor Hugo's works, etc. Bryusov thoroughly introduced the peculiarities of translation of Armenian literature and gave great importance to the choice and artistic arrangement of words. Speaking about Armenia, V. Bryusov stated; Арменя-авангардъ Европы въ Азіи", i. е. Armenia is in the vanguard between Europe and Asia [1, p.92].

In the introduction, V. Bryusov presented a brief illustration and a vivid description of Armenian culture and tradition. It is unique research that comprises 
valuable facts in the sphere of literature and the art of translation and accurate depictions of the historical-political insights from the ancient Armenian period till the beginning of the 20th century. The theorist illustrates a brief history of magnificent literary and historical figures, including Mesrop Mashtoc, Sahak Partev, Movses Khorenatsi, Tigran the Great, King Trdat, kings of Cilicia, etc. In the anthology, a brief historical framework of the Armenian literature is highlighted in a strict chronological order; from the folk poetry till the poetry of the Middle Ages, ashughs' songs, new poetry - the poetry of Eastem and Western Armenians. Of particular interest is the interpretation of Gh. Alishan's literary heritage as one of the honourable members of the Mekhitarist Congregation.

Ghevond Alishan's works with their deep and ideological-philosophical content arouse great interest not only within the representatives of the Armenian intel ligentsia, but also among the well-known European scholars, translators and thinkers. V. Bryusov was one of those theorists who profoundly eval uated the works of Gh. Alishan and emphasized his exceptional poetic individuality. The Russian thinker stated; Алишаномъ написано не мало религіозныхъ стихотворений, молитвъ и гимновъ; есть поэмы, посвященный историческому прошлому Армении; есть живыя описанія природы; особую глубину стихамъ Алишана придаеть его трогательная любовь къ родине, воспламенявшаяся судьбой поэта, жившаго на чужбине [1, p.94].

Alishan was a well-known Western Armenian figure and a highly educated man of his time endowed with encyclopaedic knowledge, unique aesthetic perception, wisdom and devotion towards his nation. If we draw a paralle between two distinguished figures -V. Bryusov and Gh. Alishan, we'll observe that both had deep intellectual thought, brilliant knowledge of languages and world literature, scientific background, love and devotion towards their Motherland and nation - its cultural values and the highest level of humanism In other words, they both were outstanding figures of the epoch that made a significant contribution to the development of culture, science, literature. It is known that Alishan's literary works inspired a whole generation of writers of the era, who admired and imitated the novelty of poetic formation and the usage of unique stylistic overtones. V. Bryusov was a talented and gifted poet who entertained novice strategies to improve Russian versification, raising it to a new, higher level.

The philosophical brilliance, aesthetic elegancy and wisdom of Alishan's creativity impacted Russian theorists and translators, thus becoming the keystone for literary inspiration. V. Bryusov underlined that Alishan achieved great perfection in the technique of verse, and his works inspired a significant number of readers as sincere and beautiful pieces of verbal creativity.

In this connection, A vetik Isahakyan, a devotee Varpet of the Armenian people, greatly admired Alishan's works. Meeting Gh. Alishan in the monastery of the 
Mkhitarists was memorable for the writer. In his memoirs, he wrote that he looked forward to seeing beloved Alishan, whose name and creative work greatly influenced contemporary writers. They all knew the beautiful poems of the Patriarch, woven with attractive power of devotion towards Motherland, like "Hrazdan", "Nightingale of Avarayr", etc. Characterizing Alishan's literary heritage, Isahakyan highlighted the significance of his books, which had a comprehensive scientific background and inspired many generations to respect and admire education and knowledge. Alishan's geographical works entitled "Ayrarat", "Shirak", "Sisakan" outline Armenia's basic information as an impeccable gem of the ancient civilization, flavoured with praising overtones towards the cherished places of the homeland. [4].

The scrutinized research of the creativeliterary works of the Armenian poets has shown that from ancient times till now, they flavoured their style and language with unique linguistic elements, imagination and aesthetic perceptions that transmitted the reader a peculiar message about moral and wisdom divinity, love and compassion and certainly the sorrow for Motherland. Being experts in philology and translation studies, Russian theorists underlined the relevance of transmitting the "aesthetic atmosphere" in the target text to reinforce the intertwinement of expressive-emotionalevaluative overtones, stylistic devices and the pictorial expressiveness of the original. Thus, in an introductory part, V. Bryusov briefly described Russian translators' translation mechanisms and strategies for compiling the anthology of Armenian literature. He stated that they are mainly based on unique linguistic expressions and the interplay between the sounds and meanings. Extra-linguistic factors were al so taken into consideration accompanying the analysis of the literary creation epoch, religious, cultural and traditional, socio-political condition, etc. V. Bryusov claimed that the assessment of translation efficiency and its dignity did not belong to him, still, he spoke about the mechanisms and peculiarities of translation procedure done in the anthology. First of all, the translator became familiar with the original as far as possible. It was done through literal interlinear translations and correct transcriptions of the Armenian text, thus informing the translator about the rhythmical and prosodic features of the original. The theorists made proficient editions and improvements of translations to illustrate an accurate reverberation of the original so that the reader could perceive the aesthetic texture of the Armenian original. In particular, Bryusov believed that literary translations should accurately convey the content of the original and reproduce all the characteristic features of its form One of the complex procedures of literary translation was the choice of the equivalent prosodic features and verse corresponding to the meter and rhythm of the original. The difference in the versification of the Russian (tonic) and Armenian (syllabic) led to some reproductions; however, as Bryusov stated, they did not focus on pedantry preservations of form which conditioned the language itself, just the contrary, they ai med at the recreation of the original; the formation of the stanza, rhythmic peculiarities, etc. Finally, persistent 
attention was paid to illustrating the phono-stylistic devices; assonances, alliteration, onomatopoeia. Bryusov used unique linguistic terminological elements as "звукопис" (sound pattern and sound imagery) and "словесной инструментовки" (verbal creativity or verbal instrumentation) for underlying the concept of style and language which constitutes a unique charm of medieval Armenian lyrics. As for the content, proximity to the original text prevailed since the spirit of the Armenian narration, its images and characters should be illustrated [6, p.32].

On the development of Russian-Armenian literary relations, a vital role can be given to the Russian poet-translator, critic Yuri Veselovsky, a great connoisseur and popularizer of Armenian literature and culture in general. Numerous studies of Vesel ovsky from Armenian literature all owed him to conclude that Armenian poetry of the 19th century, like all new Armenian literature in general, is divided into two main branches [2, p.8]; the Eastern, which includes Armenian writers whose cultural centre was Tiflis, partly Moscow and St. Petersburg and Western Armenian writers, who lived and held their activities in Constantinople.

Drawing parallels between these two branches, Veselovsky pointed out their distinctive features by stating that Western Armenian writers al ways focused on the ratio of form and structure to convey the beauty and grace narration. Sometimes, there was the detriment of the inner content for the sake of aesthetics. Eastern Armenian writers, on the contrary, assigned a prominent place in their work to the ideological and tendentious motives, sometimes not paying particular attention to the careful construction of the syllable [2, p.8]. The reason of the distinctive features between two branches Veselovsky interpreted as follows: «Если закавказские поэты до последнего времени лишены были возможности правдиво и ярко отражать в своём творчестве участь армянского народа в пределах России, то страдания армян затрагивались ими гораздо смелее и полнее, чем константинопольскими поэтами, имевшими дело с турецкою цензурою» $[2$, p.9]. Moreover, living in Constantinople, Western Armenian writers had censorship restrictions to depict their lifestyle and inner sorrow, unlike the Eastern Armenians. Finally, carrying out a particular chronological survey of the history and development of A menian literature, Vesel ovsky underlined the literary-scientific and educational activity of the Mekhitarist Congregation. Their members were the representatives of Western A rmenia.

\section{THE COMPARATIVE ANALYSIS}

The theme of the exiled Armenians from Motherland revolved around most Armenian poets and was predominant in the late 19th - early 20th centuries. Alishan lived and created in the Mekhitarist Congregation (Venice), admiring and translating various European writers and masterpieces into Armenian. Still, he remained faithful to his people's national traditions, moral and ideological values till theend of his life. 
Thus, his works are "eternal" for the Armenian nation, and his poetic discourse illustrates the intense feeling of Patriotism

The touching love for the Motherland lies behind the texture of Alishan's poem Hrazdan - the poet's fate exiled from his native land. Let's discuss an extract from the poem

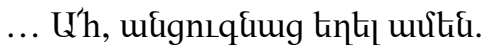 \\ U'h, ungnsquaug $t$ <ujuuunud, \\ 2hu ufưtilhl pnпuo uuuter

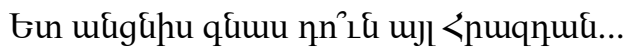

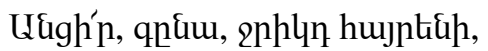 \\ Unununıfup htipp te fupltidh: [2, p. 3] \\ ... Прошло, исчезло все. Ушла, \\ Исчезла матерь Айастан. \\ Я одинок здесь, у русла. \\ И мимо ты бежишь. Раздан. \\ Беги! Ты многое унес.
}

Довольно мне, Бабкену, слез ! [1. p. 13]

(Пер. С. Шервинского).

The poem's translator Shervinsky, proudly considered himself V. Bryusov's student. In 1916 he debuted both as a poet and translator by publishing his translations in the anthology Poetry of Armenia from Ancient Times to the Present Day. Later he translated some works by $\mathrm{H}$. Tumanyan and other famous writers. Stravinsky's great interest and admiration for Armenia and its culture served as an excellent impetus for creating and translating wonderful poems reflecting his sincere feelings towards the ancient sacred land.

The poem reveals the character's (Babken's) lament and mourns for his land, nation, relatives, beloved and neighbours, reverberating the entire grief of the Armenians. The thematic structure is based on the character's inner monologue with the river Hrazdan reinforcing the idea of transient life. Babken's quest for re-creating the life of Armenians alongside the river was in vain and useless, and everything passed. The idea is especially stressed in the last stanza, where there is an artistic

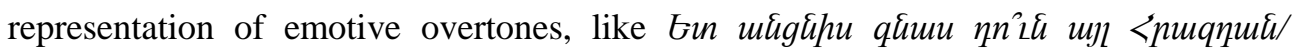

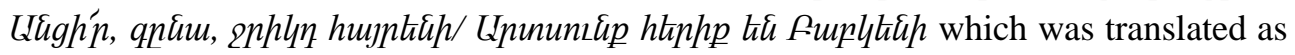
И мимо ты бежишь. Раздан/ Беги! Ты многое унес/ Довольно мне, Бабкену, слез. The quintessential notion of the passage is; as the river Hrazdan was flowing thoughtless, taking away the pain and sorrow, Babken also must wipe away his tears and re-evaluate his life 
At the end of the anthology, Bryusov thoroughly elaborated special notes and references devoted to the pivotal creative activities of Armenian writers from ancient times till the beginning of the $20^{\text {th }}$ century. In one of his notes, Bryusov truthfully stated that the revival of Armenian literature is closely connected with the activities of the Mekhitarist Congregation, with particular reference to Mkhitar Sebastaci. Referring to Gh. Alishan, whose artistic gems were focused in Venice, the Mekhitarist Congregation, Bryusov referred to Alishan's important work entitled as "<ujng Enqp ก-uúluuluuup-Armenian Popular Songs".

"Armenian Popular Songs" is a series of unique Armenian troubadour (ashugh) and folk songs, compiled and translated by Ghevond Alishan, who exclusively aimed at preserving the spiritual strength of ethnocultural nuances of the Armenian nation and the deep love and devotion for the homeland. First, let's refer to one of the small passages from the popular songs.

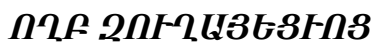

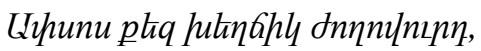

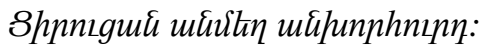

\section{TheArmenians in Emigration from Old Ciulfa}

Woeto ye poor Armenian people!

Without a fault and a thought, ye have been scattered.

(Gh. Alishan, Armenian Popular Songs)

Pointing to the peculiarities of Alishan's literary style, his pure love for the Motherland and his inner thoughts of his nation are noticeable. Alishan's love and inspiration towards Armenia led him to a primary stimulus to create poetry full of aesthetics, Patriotism and literary taste, like You, Armenian country, I mourn, Masis mountains, and Nightingale of Avarayr devoted to the national hero Vardan Mamikonyan, who died on the Avarayr fields on J une 2, 451 for the Motherland Armenia

\section{CONCLUSION}

Russian-A menian literary relations flourished at the beginning of the twentieth century. Famous Russian poets and theorists brilliantly reverberated Armenian literature through the prism of the Russian translation.

The Russian translation of Gh. Alishan's poem Hrazdan unfolds the target reader the Armenian patriotic thought, the depth of the national wounds illustrating the 
traumatic experience of those cataclysmic times. It depicts the style and language of the author interwoven with the intellectual, aesthetic and literary sensitivity.

Hence, the Armenian poetic voice found its unique manifestation in Russian, comprehensively illustrating its intellectuality, depth of thought and feling, and ancient roots.

\section{REFERENCE}

1. Armynskay poezia $v$ perewodax $V$. Brusova. Pod red. A. Idgikyana. Y erevan. Armyanskoe gosudarstvennoe izdatelstwo. 1956. 319 p. (In Russian).

2. Armianskaia muza: sbornik. Izdannyi pod red. I.U. Veselovskago i prof. G. A. Khalatiantsa.Tipo-litogr. T-va I. N. Kushnerev, 1907. //U.Veselovski. Neskolko slov o novoi armynskoe poezii. 184 p. (In Russian).

3. G. Alishan. Banastexteuteunner.//http://armenianhouse.org/alishan/poemsamhtrml (In Armenian).

4. Avetic Isaakyan. Gevond Alishyan. //Hayoc jamanak № 34. 22.05. 17.

5. Mkrtchan L. Esli bi v Vavilone bili perevodghiki. Y erevan. Sovetakan grogh. 1987. (In Russian).

6. Poesia Armenii s drevneyshix vremen do nashix dney $v$ perevodah russkix poetov/pod redakciey, so vstupitelnim ocherkom, primechaniem V. Bryusova, $v$ izdanie, Y revan, Haypetrat, 2017, 408 p. (In Russian).

7. Fedorov A. Osnovi obshey teorii perevoda. M. : Vishaya shkola. 1983. 205 p. (In Russian). 